\title{
Enterococcus hirae
}

National Cancer Institute

\section{Source}

National Cancer Institute. Enterococcus hirae. NCI Thesaurus. Code C86371.

A species of facultatively anaerobic, Gram-positive, cocci shaped bacteria in the phylum Firmicutes. This species is nonmotile, non-spore forming, catalase negative, and hydrolyzes esculin but not hippurate. E. hirae was isolated from chicken and pig intestines and though rare, is pathogenic in humans. 